\title{
A Comparison between Three Dimensional Radiation Therapy and Intensity Modulated Radiation Therapy on Prostate Cancer
}

\author{
YoungJae Kim, JaeSub Lee, Seongill Hong, HyeJin Ko* \\ Dept. of Radiological Technology, Gwangyang Health College, \\ Dept. of Radiation Oncology, Chosun University Hospital

\section{전립샘암의 방사선 치료 시 입체조형치료법와 세기조절방사선 치료법의 비교}

\author{
김영재, 이재섭, 홍성일, 고혜진
}

광양보건대학교 방사선과, 조선대학교병원 방사선종양학과*

\begin{abstract}
In this study, we evaluated to the superiority of treatment techniques on prostate cancer, apply to each other treatment techniques -3D conformal therapy versus IMRT- using dose distribution and dose coverages. Obtained 10 patients CT simulation, divided tumor volume and critical organs. Prescription dose was $80 \mathrm{~Gy}$ on tumor volume and Each of plans was set by two different plans. As a result, Dose coverage was superior to IMRT. The IMRT's tumor absorbed dose $(100.2 \%)$ was close to prescription doses. Normal tissue(bladder, rectal, bowel Lt·Rt fumoral head) absorbed dose rate was superior. In other words, the radiation therapy of prostate cancer with intensity modulated radiation therapy was better than conformal radiation therapy on dose.
\end{abstract}

Key Words: 3D-Conformal Radiation Therapy, IMRT, Prostate cancer

\section{요 야}

본 연구에서는 전립샘암 환자에게 방사선 치료법인 3 차원 입체조형법과 세기조절치료법을 각각 적용 할 경우 선량 분포의 차이를 관찰하여 치료기법의 우수성을 평가하고자 하였다. 실험대상자 10 명의 컴퓨터 단층 모의치료영상을 얻 어 종양학과 전문의가 종양용적 및 정상장기를 구분하고 종양용적에 흡수선량을 $80 \mathrm{~Gy}$ 로 설정한 후 각각 다른 치료계 획을 수립하였다. 그 결과 선량분포윤곽은 세기조절치료법이 우수 하였고 종양조직의 흡수선량은 세기조절치료법이 처방선량에 근접(100.2\%)하였으며 정상조직 흡수율(방광, 직장, 소장, 좌·우 대퇴골두) 또한 우수하였다. 즉, 전립샘 암의 방사선 치료시 세기조절방사선치료가 입체조형치료법보다 선량적인 면에서 양호한 것으로 분석되었다.

중심단어: 입체조형치료, 세기조절방사선치료, 전립샘암

\section{I. 서 론}

방사선 치료의 원리는 종양조직에 처방선량을 조사
하며 인접하는 정상조직 및 결정 장기에는 가능한 흡 수선량이 적게 하여 정상조직의 부작용이 나타나지 않도록 하는 것이다. 이러한 원리하에 방사선치료기술 또한 발전해 왔다 ${ }^{[1]}$. 특히, 1980년대 후반부터 1990년
Cor responding Author: HyeJin Kor E-mail :witch0505@gmail.com
Add. (501-717) Dept. of Radiation Oncology, Chosun University Hospital

Received: October 02, 2013 
대 초반에 급격한 발전을 이루었는데 이는 컴퓨터 단 층촬영기(computed tomography, CT)의 개발과 종양학 과의 방사선치료계획에로의 적용 때문인 것으로 평가 된다. 컴퓨터 단층촬영기의 도입은 기존의 평면화되고 아날로그적인 방식인 2차원 방사선치료(two dimensional radiation therapy, 2DRT)를 3차원방사선치료 (three dimensional conformal radiation therapy, 3DCRT)로 발전하게 하는 직접적인 원인이 되었다 ${ }^{[2]}$. 이는 기존 의 치료법보다 종양조직에 적합한 처방선량을 부여하 며 정상조직에는 더 적은 선량을 부여할 수 있게 하였 다. 한편, 다엽콜리메이터(multi-leaf collimator, MLC)의 개발과 발전은 종양조직에 인접한 정상조직의 차폐가 용이해져 기존의 3 차원치료보다 치료범위 내의 종양 조직에 더욱 균일하고 균등한 선량을 부여할 수 있게 되었으며 특히, 주요정상조직이 많은 곳에 호발한 종 양조직의 방사선 치료에 적합하게 적용할 수 있게 되 었다 ${ }^{[3]}$. 이를 세기조절방사선치료법(intensity modulated radiation therapy, IMRT)이라고 명명 하였으며 기존의 3 차원 치료법보다 치료효과비가 높은 것으로 보고되고 있다 ${ }^{[4]-[6]}$

이에 본 논문에서는 전립샘암 환자를 대상으로 방 사선치료를 3 차원 치료와 세기조절방사선치료로 각각 계획하여 선량분포양상(dose coverage))과 선량체적곡선 (dose volume histogram, DVH)을 분석하여 상호비교 하 고자 한다.

\section{II. 실험 대상 및 방법}

\section{1. 실험기기 및 대상}

실험에 사용한 의료용 선형가속기로는 varian 사의 21EX (philips, USA)를 사용하였으며 모의치료영상의 획득은 컴퓨터 단층 모의치료장치인 Brilliance Big Bore 를 이용하여 영상을 획득하였으며 획득된 영상은 치 료계획 장치인 eclipse 8.6.17을 이용하여 치료계획을 실 시하였다[Fig. 1], [Fig. 2].

실험대상으로는 $\mathrm{C}$ 병원에서 전립샘암을 확진 받고 방사선치료를 시행받은 환자 10 명을 대상으로 하였으 며 연구에 참여하는 대상자들은 모두 본 연구의 목적 과 방법에 대해 충분히 이해하였다.

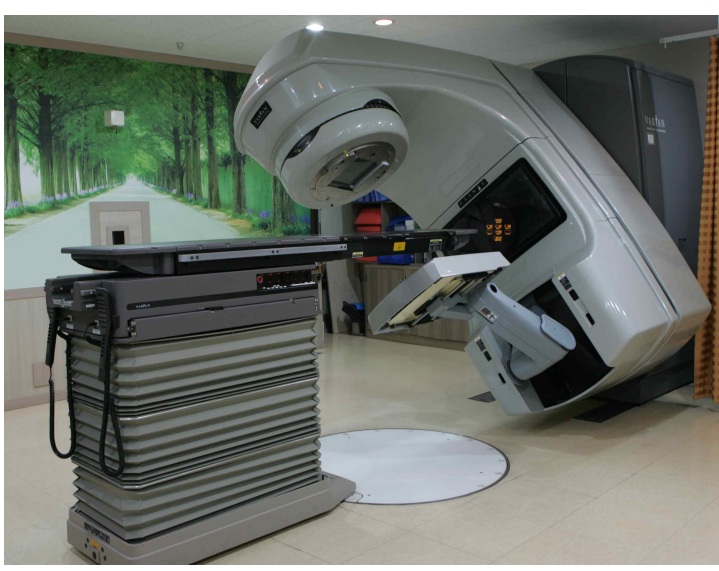

Fig. 1. Linac (varian 21EX, philips, USA).

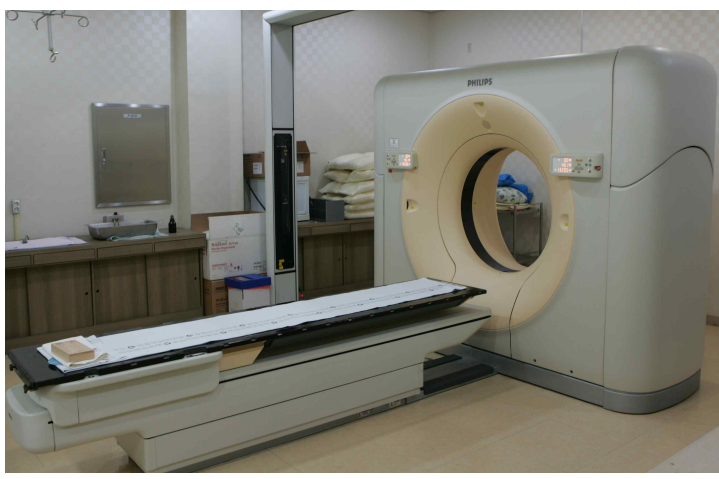

Fig. 2. CT simulator (Brilliance Big Bore).

\section{2. 실험방법}

CT 모의치료장치를 이용하여 1 번 요추부터 대퇴골 중간부분까지 $3 \mathrm{~mm}$ 두께의 단층영상을 획득하였다. 획득된 영상을 바탕으로 방사선종양학과 전문의가 종 양조직(planning target volume, PTV)과 정상조직(normal oirgan)의 영역을 설정하였다. 대표적인 정상조직은 직 장(rectal), 방광(bladder), 소장(bowel), 좌·우의 대퇴골두 (Lt and Rt femoral head)로 정하였다. 종양조직과 정상 조직이 설정된 모의치료영상을 바탕으로 종양용적에 $80 \mathrm{~Gy}$ 가 흡수되도록 하여 2가지 치료계획으로 나누어 수립하였다.

2 가지의 치료계획은 각각 4 문 조사 box 형 치료법 과 8개의 방향으로 치료를 실시하는 IMRT 방식으로 나누었다. 


\section{2. 분석방법}

2 가지 상이한 치료계획의 상호 분석은 첫째, $95 \%$ 등선량곡선의 coverage 양상과 둘째, 선량체적곡선 $(\mathrm{DVH})$ 의 상호 분석. 셋째, PTV의 최소(Dmin) 및 최대 (Dmax) 선량값 그리고 평균선량값(Dmean)을 상호 비 교하도록 한다.

\section{III. 결 과}

\section{1. 등선량 분포의 양상}

치료계획을 달리한 경우의 등선량 분포의 양상을 살펴보면 3차원 입체조형치료법 즉, 4 문 box 형 조사 법을 사용하였을 경우의 선량 집중영역이 IMRT보다 큰 면적으로 나타난 것을 알 수 있었으며 방사선이 지 나가는 영역의 정상조직 부분에 고선량이 관찰 된 것 을 알 수 있었다[Fig. 3].

Fig. 4에서는 등선량 분포를 $95 \%$ 이상 선량이 흡수되 는 면적만 표시되는 영상이며 이 영상에서는 4 문조사 의 경우가 IMRT보다 직장에 입사되는 선량이 높게 나 타는 것을 관찰 할 수 있으며[Fig. 4. $\bigcirc$ 부분] 관상면, 시상면 영상에서도 등선량분포의 양상이 PTV에 더 적 합하게 나타난 것을 육안으로 확인할 수 있었다.

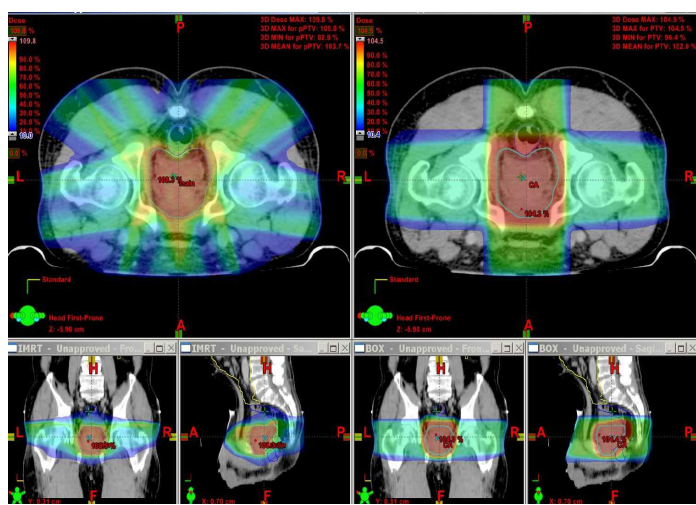

Fig. 3. Dose coverage of IMRT and 3D-CRT.

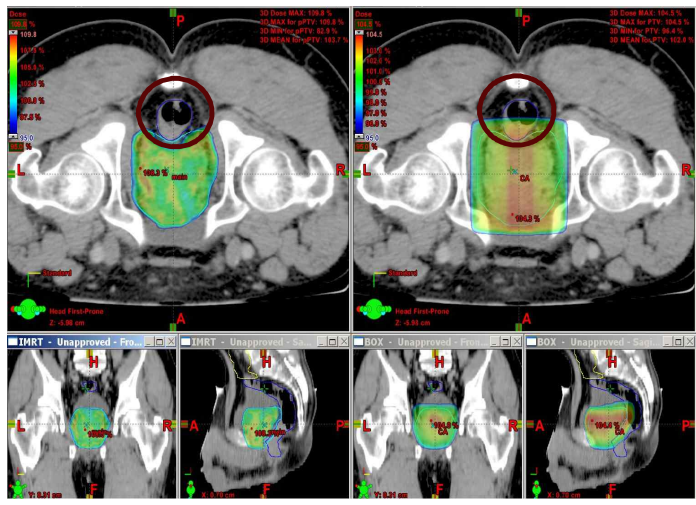

Fig. 4. Over the $95 \%$ dose coverage of IMRT and 3D-CRT.

\section{2. 선량체적곡선(dose volume histogram, DVH)} 의 비교

\section{1 종양조직의 선량체적곡선}

$80 \mathrm{~Gy}$ 의 처방선량을 설정하고 실제 PTV에 흡수되 는 선량을 확인해본 결과 IMRT 치료계획의 경우 최소 $50.55 \mathrm{~Gy}$ 의 흡수선량을 보였으며 최대선량은 $85.63 \mathrm{~Gy}$ 의 선량을 보여 평균 $80.18 \mathrm{~Gy}$ 의 선량을 보였다. 반면 에 4문조사법인 경우 최소 및 최대선량은 각각 75.21 $\mathrm{Gy}$ 와 $81.50 \mathrm{~Gy}$ 의 선량을 보였으며, 평균선량은 79.52 의 선량을 나타냈다. IMRT와 4문조사법 모두 처방선량인 $80 \mathrm{~Gy}$ 에 근접한 선량이 흡수된 것으로 관찰 되었으나 선량체적곡선 상에서 나타난 바와 같이 IMRT의 치료 계획이 종양조직에 더욱 적합한 선량흡수양상으로 관 찰되었다[Fig. 5], [Table 1].

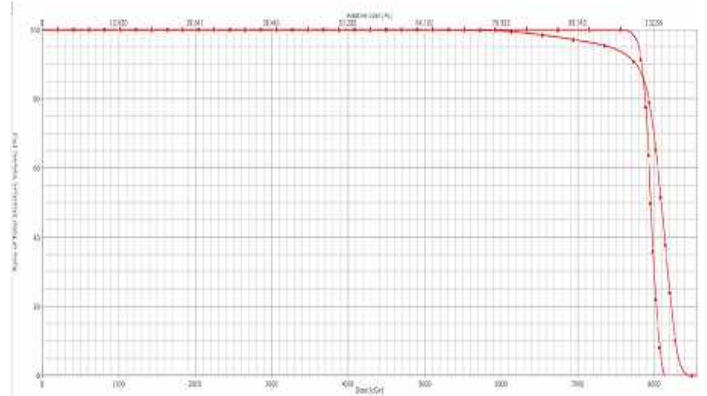

Fig. 5. Dose volume histogram of PTV on IMRT versus 4 portal RT.(IMRT: square dots, 4 Portal RT: triangle dot) 
Table 1. Information on PTV of IMRT and 4 Portal RT.

\begin{tabular}{cccccc}
\hline & $\begin{array}{c}\text { Volume } \\
\left(\mathrm{cm}^{3}\right)\end{array}$ & $\begin{array}{c}\text { Dose } \\
\text { Cover (\%) }\end{array}$ & $\begin{array}{c}\text { Min } \\
\text { Dose(Gy) }\end{array}$ & $\begin{array}{c}\text { Max } \\
\text { Dose(Gy) }\end{array}$ & $\begin{array}{c}\text { Mean } \\
\text { Dose(Gy) }\end{array}$ \\
\cline { 1 - 4 } IMRT & \multirow{2}{*}{277.6} & \multirow{2}{*}{100} & 50.55 & 35.83 & 80.18 \\
\cline { 1 - 3 } CRT & & & 75.21 & 31.50 & 79.52 \\
\hline
\end{tabular}

\section{2 정상조직의 선량체적곡선의 비교}

1) 직장의 선량체적곡선

IMRT 치료계획의 경우 최소 $2.54 \mathrm{~Gy}$ 의 흡수선량을 보였으며 최대선량은 $70.29 \mathrm{~Gy}$ 의 선량을 보여 평균 $28.62 \mathrm{~Gy}$ 의 선량을 보였다. 반면에 4 문조사법인 경우 최소 및 최대선량은 각각 $1.61 \mathrm{~Gy}$ 과 $80.96 \mathrm{~Gy}$ 의 선량 을 보였으며, 평균선량은 $45.86 \mathrm{~Gy}$ 이었다. 4문조사법인 경우가 IMRT 치료계획선량보다 평균 흡수선량이 높 았으며 이는 정상조직인 직장에 장해가 발생할 확률 이 높아진다는 것을 의미한다[Fig. 6], [Table 2].

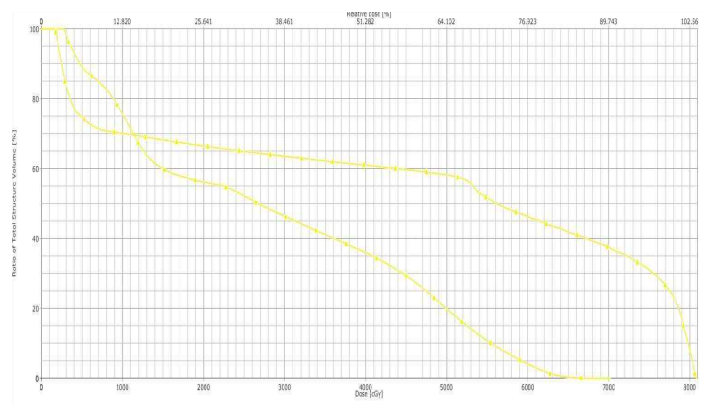

Fig. 6. Dose volume histogram of bowel dose on IMRT versus 4 portal RT.(IMRT: Square dots, 4 Portal RT: Triangle dot)

\section{2) 방광 선량체적곡선}

IMRT 치료계획의 경우 최소 및 최대 흡수선량은 각각 $4.35 \mathrm{~Gy}$ 와 $35.83 \mathrm{~Gy}$ 으로 평균선량은 $50.18 \mathrm{~Gy}$ 이 었다. 4문조사법인 경우 최소 및 최대선량은 각각 2.91 $\mathrm{Gy}$ 와 $21.50 \mathrm{~Gy}$ 의 선량이 흡수되었고, 평균선량은 66.73 $\mathrm{Gy}$ 이었다. 직장과 마찬가지로 4문조사법인 경우의 방 광의 흡수선량이 높았으며 이는 정상조직인 장해가 발생할 확률이 높아진다는 것을 의미한다[Fig. 7], [Table 2].

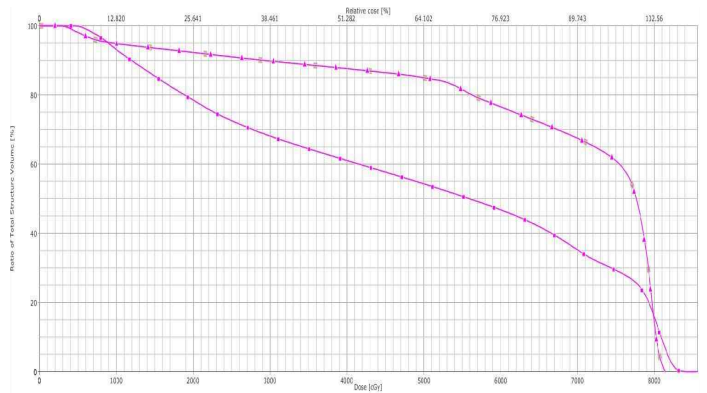

Fig. 7. Dose volume histogram of bladder dose on IMRT versus 4 portal RT.(IMRT: Square dots, 4 Portal RT: Triangle dot)

3) 소장 선량체적곡선

최소 및 최대 흡수선량 IMRT 치료계획이 각각 $0.001 \mathrm{~Gy}$ 와 $2.97 \mathrm{~Gy}$ 으로 평균선량은 $0.19 \mathrm{~Gy}$ 이었고 4 문조사법인 경우에는 각각 $0.00 \mathrm{~Gy}$ 와 $1.68 \mathrm{~Gy}$, 평균선 량은 $0.225 \mathrm{~Gy}$ 이었다. 매우 적은 선량이 흡수됨에도 불구하고 4 portal RT의 경우가 다소 방사선흡수량이 높은 것으로 관찰되었다[Fig. 8], [Table 2].

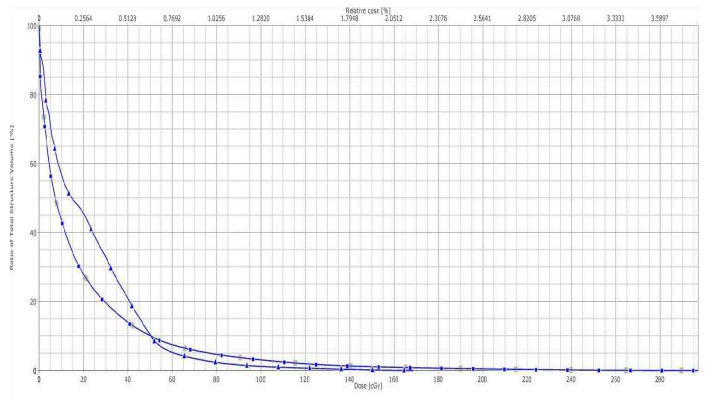

Fig. 8. Dose volume histogram of bowel dose on IMRT versus 4 portal RT.(IMRT: Square dots, 4 Portal RT: Triangle dot)

3) 좌·우 대퇴골두의 선량체적곡선

IMRT 치료계획의 경우 좌측 대퇴골두의 최소, 최 대, 평균 흡수선량은 각각 $18.33 \mathrm{~Gy}, 38.76 \mathrm{~Gy}, 27.62 \mathrm{~Gy}$ 이었으며 4 portal RT의 경우 $32.66 \mathrm{~Gy}, 36.18 \mathrm{~Gy}, 34.44$ $\mathrm{Gy}$ 이었다.

우측 대퇴골두의 흡수선량은 IMRT의 경우 최소, 최대 및 평균 흡수선량은 각각 $12.48 \mathrm{~Gy}, 39.33 \mathrm{~Gy}$, $27.07 \mathrm{~Gy}$ 이었으며 4 portal RT의 경우 $33.62 \mathrm{~Gy}, 37.16$ $\mathrm{Gy}, 35.07 \mathrm{~Gy}$ 이었다.

좌.우측의 대퇴골두에 흡수되는 선량을 비교한 결 
과 최대선량값을 제외한 모든 선량적인 측면에서 IMRT치료법이 3차원 입체조형치료법보다 적은 방사 선흡수량을 보였다[Fig. 9], [Table 2].

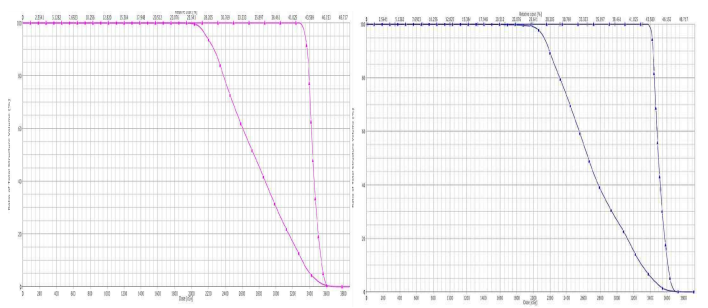

Fig. 9. Dose volume histogram of $L t$ and Rt Femur Head. on IMRT versus 4 portal RT.(Left: Lt Femur Head, Left: Rt Femur Head, IMRT: Square dots, 4 Portal RT: Triangle dot)

\section{IV. 고 찰}

Three dimensional conformal radiation therapy가 전립 선암에 적용되어 PTV 선량을 증가시킴으로 국소제어 율의 상승 이라는 장점은 나타내어 고무적이었으나, 상대적으로 높은 PTV 선량 때문에 관심장기의 흡수선 량이 증가되어 합병증의 빈도가 높아지게 되었다. Deamaly 등은 3D-CRT 기법을 이용하여 전립선에 64 $\mathrm{Gy}$ 를 조사했을 때, 전립선암에서 완화치료법에 비해 부작용이 $10 \%$ 감소함을 보고하였고 ${ }^{[7]}$, Nutting 등은 전 립선암에서 IMRT를 사용하여 위험장기에 대한 방사 선량이 감소함을 보고하였다 ${ }^{[8]}$. Price 등은 전립선암에 서 IMRT를 시행할 때 non-coplanar 빔을 사용하여 위 험장기에 대한 방사선량을 감소시킬 수 있다고 보고
하였고, 또한 세기조절방사선치료에서 방사선의 조사 시간이 $6 \mathrm{MV}$ 에너지를 사용할 때는 10 분에서 25 분의 시간이 소요되었으며, $10 \mathrm{MV}$ 나 $18 \mathrm{MV}$ 의 에너지를 사 용할 때는 조사시간이 7 분에서 18 분이 소요되었다고 보고하였다 ${ }^{[9]}$. 또한, 전립선암에서 세기조절방사선치 료의 장점으로 PTV 선량분포를 더욱 좋게 하며, 치료 시간을 감소시키는 것이라고 보고하였다 ${ }^{[10]}$.

본 연구에서 얻은 PTV의 선량을 관찰해 보면 최소 선량은 3D-CRT의 경우가 IMRT 보다 $14.88 \%$ 정도 더 많은 선량을 보인 것으로 관찰되었으며 최대선량은 오히려 IMRT가 $11.37 \%$ 많은 선량 흡수를 보였다. 평 균 흡수선량은 IMRT가 $100.2 \%, 3 \mathrm{D}-\mathrm{CRT}$ 의 경우가 $99.4 \%$ 의 선량을 보여 두 치료법 모두 처방선량의 허용 범위를 초과하지 않았다. 정상조직의 흡수선량을 살펴 보면 직장의 경우 IMRT치료법의 경우 3DCRT보다 평 균흡수선량을 $37.50 \%$ 감소시킬 수 있었으며 방광의 경 우도 $25.51 \%$ 감소시킬 수 있었다. 소장의 경우도 $17.39 \%$ 선량의 감소를 보였으며, 좌·우의 대퇴골두도 각각 $17.39 \%, 22.90 \%$ 의 선량 흡수율을 낮출 수 있었다. 정상조직에 견딤선량 이상의 방사선이 흡수될 경우 이로 인한 손상위험장기 혹은 정상조직의 만성 합병 증이 발생할 수 있는데 특히, 골반의 경우 흔히 나타 날 수 있는 만성 합병증으로는 장 폐색, 장 천공 혹은 괴사, 장출혈 및 신경손상 등이 있다 ${ }^{[11]}$. 방광의 경우 방광염, 방광천공, 폐색이 관찰되며, 고관절의 경우에 는 무혈성 괴사등의 환자의 삶의 질에 심각한 영향을 끼칠 수 있다 ${ }^{[12]}$

Table 2. Information on Normal Tissue of IMRT and 4 Portal RT.

\begin{tabular}{|c|c|c|c|c|c|c|}
\hline & RT Techniques & $\begin{array}{c}\text { Volume } \\
\left(\mathrm{cm}^{3}\right)\end{array}$ & $\begin{array}{c}\text { Dose } \\
\text { Cover }(\%)\end{array}$ & $\begin{array}{c}\text { Min } \\
\text { Dose(Gy) }\end{array}$ & $\begin{array}{c}\text { Max } \\
\text { Dose(Gy) }\end{array}$ & $\begin{array}{c}\text { Mean } \\
\text { Dose(Gy) }\end{array}$ \\
\hline \multirow{2}{*}{ Rectal } & IMRT & \multirow{2}{*}{96.3} & \multirow{2}{*}{100} & 2.55 & 70.30 & 28.62 \\
\hline & $30-C R T$ & & & 1.61 & 31.00 & 45.86 \\
\hline \multirow{2}{*}{ Bladder } & IMRT & \multirow{2}{*}{182.2} & \multirow{2}{*}{100} & 4.35 & 35.83 & 51.20 \\
\hline & $30-C R T$ & & & 2.92 & 31.50 & 68.73 \\
\hline \multirow{2}{*}{ Bowel } & IMRT & \multirow{2}{*}{3031.2} & \multirow{2}{*}{100} & 0.00 & 2.97 & 0.19 \\
\hline & $30-C R T$ & & & 0.00 & 1.69 & 0.23 \\
\hline \multirow{2}{*}{ LT Femur Head } & IMRT & \multirow{2}{*}{59.3} & \multirow{2}{*}{100} & 18.33 & 38.77 & 27.62 \\
\hline & $30-C R T$ & & & 32.67 & 36.19 & 34.45 \\
\hline \multirow{2}{*}{ RT Femur Head } & IMRT & \multirow{2}{*}{65.8} & \multirow{2}{*}{100} & 12.48 & 39.33 & 27.07 \\
\hline & $30-C R T$ & & & 33.62 & 37.16 & 35.11 \\
\hline
\end{tabular}


정상조직 부작용의 측면에서 관찰해본 결과 IMRT 치료법이 좀 더 치료효과가 좋은 치료법으로 판단된 다. 본 연구결과와 $\mathrm{Kim}$ 등이 연구한 결과와 비교해본 다면 PTV의 선량흡수율(101.9\%)은 거의 비슷하였으며 정상조직의 흡수량과 비교한 결과도 동일한 양상을 보인 것으로 관찰되었다 ${ }^{[13],[14]}$. Rena lee 등의 연구에서 는 방광의 흡수선량의 중요성을 피력하였는데 전립샘 치료의 경우 방광의 체적에 따라 흡수선량이 변화하 는 것을 나타내어 방광조직의 보호를 주장하였다 ${ }^{[15]}$.

본 연구를 진행하면서 몇 가지 제안을 해 본다면 현 재 IMRT라는 치료 기법은 크게 의료용 선형가속기를 사용한 것과, Tomotherapy를 이용한 것, 두 가지로 나 뉠 수 있다. 치료장비가 다를 경우의 선량학적 의미를 살펴볼 필요가 있을 것이며 이미 이에 대한 연구가 상 당히 지속되고 있다. 따라서 Case By Case로 좀 더 면 밀히 연구해야 할 것이다. 유동적인 움직임을 가지고 있는 전립샘의 경우, 방광을 보호하기 위하여 체내에 고정을 위해 Rectal ballooning 법을 적용하고 있는데 이는 환자에게 불쾌감을 줄 수 있으므로 다른 고정법 을 연구해 볼 필요가 있을 것이다.

\section{$\mathrm{V}$. 결 론}

전립샘암의 방사선 치료시 입체조형치료법과 세기 조절치료법을 비교한 결과 두 치료법 모두 계획적 치 료용적에 적절한 선량분포가 나타났지만 직장 선량을 관찰한 결과 세기조절치료법이 더 양호한 선량분포를 나타냈다. 종양조직과 정상조직의 방사선 흡수량을 기 준으로 한 치료효율 또한 세기조절방사선치료가 더 우수하여 전립샘암 방사선 치료시 세기조절방사선치 료의 적용은 효과적인 것으로 나타났다.

\section{참고문헌}

[1] Perez CA, Brady LW. "Principles and practice of radiation oncology", 5th ed. Philadelphia, 5th ed, J. B. Lippincott Company, pp. 497-498, 1992.

[2] Carol MP, Grant W, bleier AR, et al. "The fieldmatching problem as I applies to the Peacock three-dimensional conformal system for modulation" Radiat Oncol Biol Phys., Vol. 34, No. 1 pp. 183-187, 1996.

[3] Chao KS, Low DA, Perez CA. "Intensity modulated radiation therapy in head and neck cancers" Radiat Oncol Biol Phy, Vol.
27, No. 1, pp.49-60, 2000.

[4] Mohan R, Wang X, Jackson A. "The potential and limitations of the inverse radiotherapy technique" Radiat and Oncol, Vol. 32, No. 3, pp. 232-48, 1994

[5] Bortfeld T, Boyer AL. Schlegel W, Kahler DL et al, "Realization and verification of three-dimensional conformal radiotherapy with modulated fields" Radiat Oncol Biol Phys , Vol. 30, No. 4, pp. 899-908, 1994.

[6] Convey DJ, Rosenbioom ME. "The generation of intensity modulated fields for conformal radiotherapy by dynamic collimation" Phys Med Biol, Vol. 37, No. 6, pp. 1359-1374, 1992.

[7] Daemaley DP, Khoo VS, Norma AR, "Comparison of radiation side-effects of conformal and conventional radiotherapy in prostate cancer:A randomised trial Lancet" The lancet, Vol. 353, No. 9149, pp. 267-72, 1999.

[8] Nutting C, Deamaley DP, Webb S "Intensity modulated radiation therapy" A clinical review. British J Radiol, Vol. 73, No. 869, pp. 459-69, 2000.

[9] Price R, Hanks E, McNeeley SW et al. "Advantages of using noncoplanar vs axial beam arrangements when treating prostate cancer with intensity-modulated radiation therapy and the step-and shoot delivery method" Int J Radiat Oncol Biol Phys, Vol. 53, No. 1, pp. 236-43, 2002.

[10] Price R, Murphy S, McNeeley SW. "A method for increased dose corformity and segment reduction for SMLC delivered IMRT treatment of the prostate" Int J Radiat Oncol Biol Phys, Vol. 57, No. 3, pp. 843-52, 2003.

[11] Perez CA, Brady LW. "Principles and practice of radiation oncology" 5th ed. Philadelphia, 5th ed, J. B. Lippincott Company, pp. 1366-1382, 2008.

[12] Michael T. Milano, Louis S. Constine, Paul Okunieff, "Normal Tissue Tolerance Dose Metrics for Radiation Therapy of Major Organs" Semin Radiat Oncol, Vol. 17, pp. 131-140, 2007.

[13] Sung Kyu Kim, Myung Se Kim, Sang Mo Yun, "Dose distribution of Intensity Modulated Radiation Therapy and 3 Dimensional Conformal Radiation Therapy in Prostate Cancer" Yeungnam University. J. of Med, Vol. 24, No. 2, pp. 538-543, 2007.

[13] Jongnam Song, Youngjae Kim, Seungill Hong, "The usability analysis of 3D-CRT, IMRT, Tomotherapy radiation theraphy on nasopharyngeal cancer", Journal of the Korean Society of Radiology, Vol. 6, No. 5, pp. 365-371, 2012,

[14] Rena Lee, Jihye Lee, Kyungja Lee et al, "Bladder Volume Variations in Patients Receiving Conformal Radiotherapy to Prostate" Korean Association For Radiation Protection, Vol. 33, No. 2, pp. 61-65, 2008. 